\title{
Empirical models for the correlation of clearness index with meteorological parameters in IRAQ
}

\author{
Dr. WaleedI . AL-RijaboZahraa M.H \\ College of Education, Dept. of Physics, Mosul University
}

\begin{abstract}
The aim of this paper is to estimate the mean monthly values of clearness index in five meteorological stations in Iraq (Mosul , Kirkuk, Rutba , Baghdad, Nasiriya) for the period (1970-2000) using different meteorological parameters .Multiple Regression Equation were used to estimate clearness index.The performance of these regression equations were evaluated by comparing the calculated clearnessindex and the measured clearness index. Several statistical tests were used to control the validation and goodness of the regression equations in terms of correlation coefficient, coefficient of determination, Mean absolute error and root mean square error. The coefficient of determination $\left(\mathrm{R}^{2}\right)$ of these multiple regression equations were very high in all stations and ranged between 0.973 to 1.00 .
\end{abstract}

\section{INTRODUCTION}

Clearness index is defined as the ratio between the global solar radiation at ground level on horizontal surface and the corresponding extraterrestrial radiation ${ }^{(\mathbf{1})}$. The monthly mean clearness index KT $=\mathrm{H} / \mathrm{Ho}$

Where $\mathrm{H}$ is the monthly mean global solar radiation on horizontal surface Ho is the monthly mean extraterrestrial radiation.Clearness index is a parameters of real importance in designing of a renewable energy sourcessystem; it can provide information concerning the read solar radiation compared with the variable solar radiation ${ }^{(2,3)}$. Clearness index can describes the attenuation of solar radiation due to clouds and aerosols and it depends on the geographical coordinates of the location for watch calculated ${ }^{(4,5)}$.

Multiple Regression Models have been Proposed for prediction of clearness index ${ }^{(6,7,8)}$. Almost all these models make use of meteorological data such as hours of bright sunshine cloudiness, relative humidity, wind speed, altitude precipitation and ambient temperature ${ }^{(9,10,11)}$.

Iraq in located between $29.5^{\circ} \mathrm{N}$ and $37.22^{\circ} \mathrm{N}$ latitude and most of its cites enjoy favorable sunshine whole year around.

In this paper correlations are proposed for monthly mean clearness index (KT) for (Mosul , Kirkuk ,Rutba, Baghdad, Nasiriya) stations based on meteorological data for the period (2000-1970)Then calculated KT are compared with measured values.

\section{MATERIALS AND METHODS}

Mean monthly values of total solar radiation, relative humidity air temperature,cloudiness,rainfall, evaporation are obtained from Iraqi meteorological organization.

The data obtained covered a period of 31 year (1970-2000)for five stations in Iraq listed in table (1) and displayed in Fig. (1).

The mean monthly value of extraterrestrial radiation $(\mathrm{Ho})$ is calculated from the following equation:

$\Phi:$ is the latitude of the location, Eo is the eccentricity correlation factor, $\delta$ is the declination, Ws is the hour angle corresponding to sun-shine or set and Isc is the solar constant having a value of $1367 \mathrm{w} / \mathrm{m}^{2}$.

The expressions of Eo , $\delta$ and Wsare given by Iqbal ${ }^{(5)}$.

$$
\begin{aligned}
& H o=\frac{24}{\pi} I s c E o \cos (\phi) \cos (\delta)\left[\sin (w s)-\frac{\pi}{180} \cos (w s)\right] \\
& E_{O}=1+0.033 \cos \left[\frac{2 \pi d n}{365}\right] \\
& \delta=23.45 \sin \left[\frac{360}{365}(d n+284)\right]
\end{aligned}
$$




\section{$W s=\cos ^{-1}(\tan \phi \tan \delta)$}

dn is the day number of the year .

Mean monthly values of clearness index were computed for the different stations during the period (1970-2000). Mean absolute error (MAE), root mean square error (RMSE), coefficient of determination $\left(\mathrm{R}^{2}\right)$, correlation coefficient (R) were used as the main criteria. The goodness of fit was judged by the size of coefficient of determination, MAE, RMSEand were computed as further check on the stability of the multiple regression equations

Table (1) : Geographical coordinate of the stations

\begin{tabular}{|c|c|c|c|}
\hline Stations & Latitude & Longitude & Altitude(m) \\
\hline Mosul & $36^{\circ} 19^{\prime}$ & $43^{\circ} 09^{\prime}$ & 223 \\
\hline Kirkuk & $35^{\circ} 28^{\prime}$ & $44^{\circ} 25^{\prime}$ & 331 \\
\hline Baghdad & $33^{\circ} 1^{\prime}$ & $44^{\circ} 24^{\prime}$ & 32 \\
\hline Rutba & $33^{\circ} 02^{\prime}$ & $40^{\circ} 17^{\prime}$ & 630 \\
\hline Nasiriya & $31^{\circ} 05^{\prime}$ & $44^{\circ} 14^{\prime}$ & 5 \\
\hline
\end{tabular}

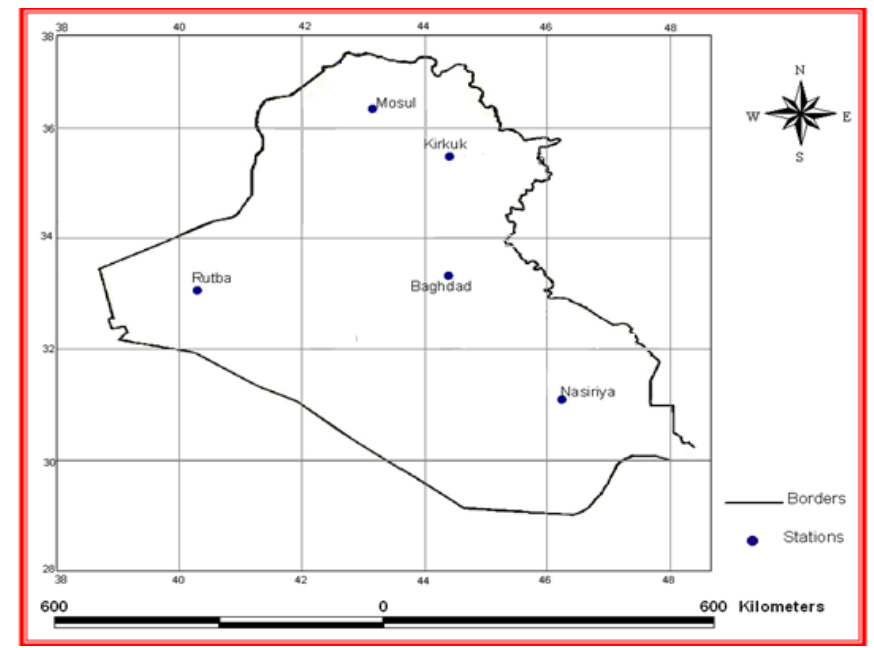

Fig (1): Location of the five meteorological stations in Iraq's

Table $(2,3,4,5,6)$ show the mean monthly meteorological parameters in all stations during the period (19702000).

Table (2):Mean Monthly meteorological parameters for Mosul station during the period (1970-2000)

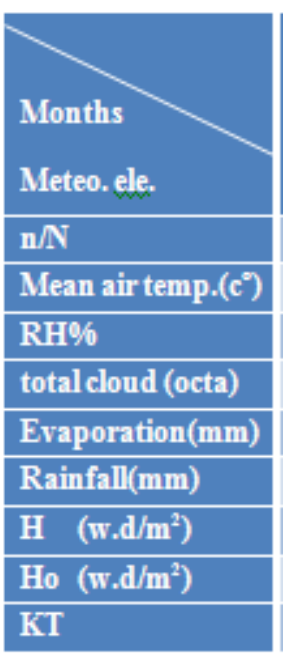

\begin{tabular}{|c|c|c|c|c|c|c|c|c|c|c|c|}
\hline JAN & FEB & MAR & APR & MAY & JUN & JUL & AUG & SEP & OCT & NOV & DEC \\
\hline 0.49 & 0.56 & 0.57 & 0.62 & 0.73 & 0.83 & 0.86 & 0.88 & 0.86 & 0.76 & 0.64 & 0.48 \\
\hline 7.0 & 8.8 & 12.6 & 18.0 & 24.5 & 30.4 & 34.1 & 33.1 & 28.4 & 21.4 & 13.8 & 8.5 \\
\hline 80.2 & 73.5 & 67.6 & 60.2 & 42.9 & 27.3 & 24.1 & 25.7 & 30.6 & 45.7 & 65.5 & 79.9 \\
\hline 4.3 & 4.2 & 4.1 & 3.9 & 2.9 & 1.1 & 0.4 & 0.3 & 0.7 & 2.3 & 3.1 & 4.7 \\
\hline 32.5 & 51.8 & 96.4 & 145.4 & 247.6 & 349.8 & 412.3 & 373.6 & 257.1 & 151.5 & 68.4 & 31.4 \\
\hline 63.2 & 62.1 & 67.8 & 43.2 & 17.0 & 1.2 & 0.2 & 0.0 & 0.3 & 11.4 & 45.1 & 60.4 \\
\hline 1996 & 2796 & 3599 & 4646 & 5559 & 6172 & 6097 & 5613 & 4845 & 3478 & 2405 & 1785 \\
\hline 4821 & 6163 & 8075 & 9876 & 11118 & 11585 & 11326 & 10324 & 8711 & 6734 & 5140 & 4400 \\
\hline 0.41 & 0.45 & 0.45 & 0.47 & 0.50 & 0.53 & 0.54 & 0.54 & 0.56 & 0.52 & 0.47 & 0.41 \\
\hline
\end{tabular}


Empirical models for the correlation of clearness index with meteorological parameters in IRAQ

Table (3):Mean Monthly meteorological parameters for Kirkuk station during the period (1970-2000)

\begin{tabular}{|c|c|c|c|c|c|c|c|c|c|c|c|c|}
\hline Montis & JAN & FEB & MAR & APR & MAY & JUN & JUL & AUG & SEP & OCT & NOV & DEC \\
\hline $\mathbf{n} / \mathbf{N}$ & 0.62 & 0.67 & 0.68 & 0.70 & 0.76 & 0.86 & 0.87 & 0.91 & 0.92 & 0.84 & 0.76 & 0.65 \\
\hline Mean air temp.(co & 9.2 & 10.8 & 14.3 & 20.2 & 26.8 & 32.3 & 35.5 & 34.9 & 31.2 & 24.9 & 16.9 & 11.0 \\
\hline RH\% & 70.9 & 65.2 & 59.2 & $\mathbf{5 0 . 6}$ & 33.4 & 22.9 & 21.1 & 22.5 & 24.8 & 35.9 & 55.9 & 70.8 \\
\hline total cloud (octa) & 3.8 & 3.7 & 3.4 & 3.3 & 2.2 & 0.5 & 0.3 & 0.3 & 0.5 & 1.9 & 3.0 & 3.7 \\
\hline Evaporation(mm) & 46.0 & 61.1 & 100.2 & 153.7 & 260.8 & 351.8 & 402.8 & 374.3 & 282.1 & 185.6 & 83.6 & 47.0 \\
\hline Rainfall(mm) & 68.3 & 66.4 & 63.1 & 47.0 & 13.8 & 0.2 & 0.3 & 0.1 & 0.6 & 12.8 & 42.9 & 60.1 \\
\hline $\mathrm{H}\left(\mathrm{w} \cdot \mathrm{d} / \mathrm{m}^{2}\right)$ & 2084 & 2827 & 3738 & 4691 & $\mathbf{5 7 3 8}$ & 6578 & 6454 & 6033 & 5159 & 3792 & 2584 & 1895 \\
\hline Ho $\left(\mathrm{w} \cdot \mathrm{d} / \mathrm{m}^{2}\right)$ & 4965 & 6294 & 8175 & 9929 & 11127 & 11570 & 11323 & 10359 & 8793 & 6855 & 5281 & 4547 \\
\hline$\overline{\mathrm{KT}}$ & 0.42 & 0.45 & 0.46 & 0.47 & 0.52 & 0.57 & 0.57 & 0.58 & 0.59 & 0.55 & 0.49 & 0.42 \\
\hline
\end{tabular}

Table (4):Mean Monthly meteorological parameters for Baghdad station during the period (1970-2000)

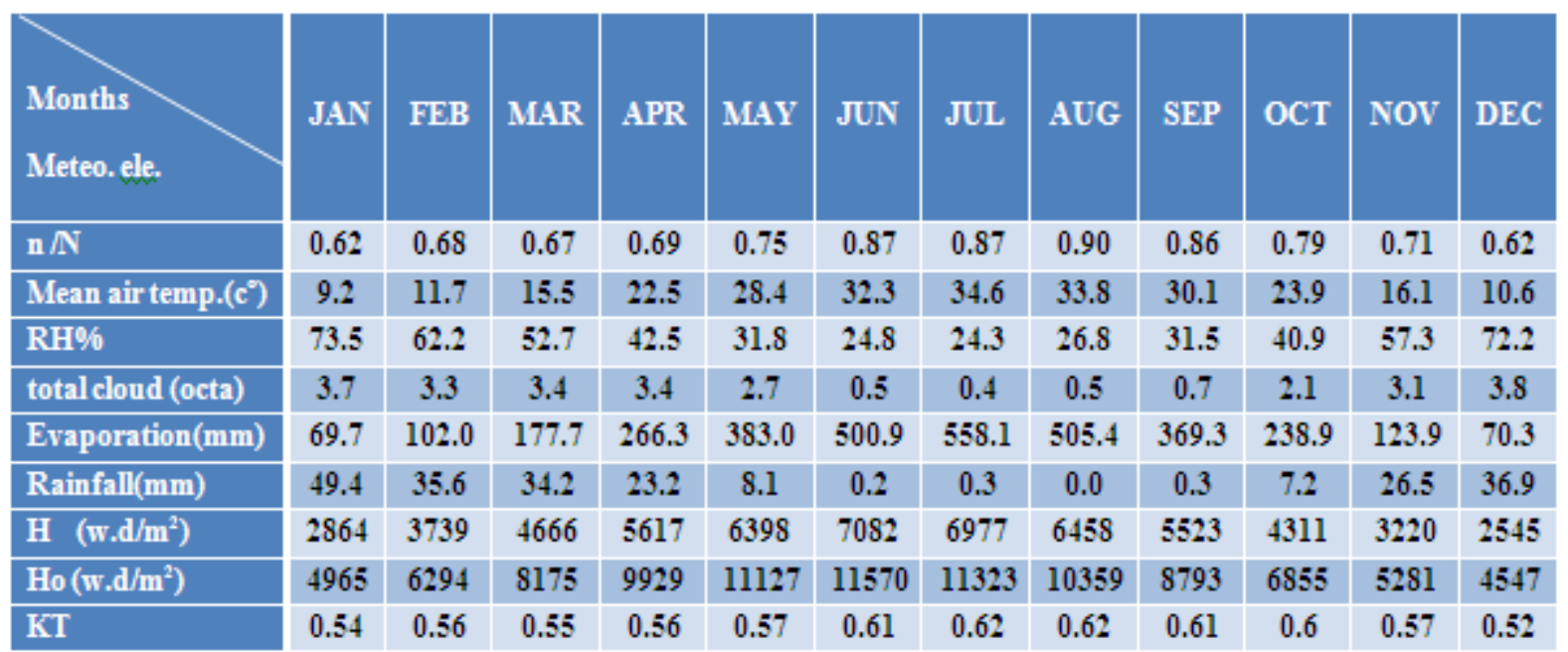

Table (5): Mean Monthly meteorological parameters for Rutba station during the period (1970-2000)

\begin{tabular}{|c|c|c|c|c|c|c|c|c|c|c|c|c|}
\hline & JAN & FEB & MAR & APR & MAY & JUN & JUL & AUG & SEP & OCT & NOV & DEC \\
\hline $\mathbf{n} / \mathbf{N}$ & 0.63 & 0.67 & 0.69 & 0.69 & 0.73 & 0.86 & 0.88 & 0.89 & 0.87 & 0.81 & 0.75 & 0.62 \\
\hline Mean air temp.(co) & 7.6 & 9.3 & 13.0 & 18.7 & 23.9 & 28.1 & 30.7 & 30.4 & 27.5 & 21.8 & 14.3 & 9.3 \\
\hline RH\% & 70.2 & 60.7 & 51.9 & 42.1 & 33.6 & 27.5 & 26.3 & 27.7 & 29.8 & 41.4 & 55.6 & 70.1 \\
\hline total cloud (octa) & 3.2 & 3.1 & 2.8 & 2.4 & 2.0 & 0.4 & 0.3 & 0.4 & 0.8 & 2.1 & 2.8 & 3.3 \\
\hline Evaporation(mm) & 77.5 & 112.5 & 186.5 & 275.2 & 378.1 & 470.0 & 556.1 & $\mathbf{5 0 7 . 5}$ & 371.1 & 247.3 & 130.2 & 78.5 \\
\hline Rainfall(mm) & 14.3 & 20.5 & 20.2 & 16.1 & 6.7 & 0.1 & 0.1 & 0.0 & 0.4 & 11.3 & 16.3 & 17.8 \\
\hline $\mathrm{H}\left(\mathrm{w} \cdot \mathrm{d} / \mathrm{m}^{2}\right)$ & 2565 & 3408 & 4381 & $\mathbf{5} 661$ & 6451 & 7198 & 7159 & 6555 & 5633 & 4345 & 3128 & 2460 \\
\hline Ho $\left(\mathrm{w} . \mathrm{d} / \mathrm{m}^{2}\right)$ & 5374 & 6663 & 8450 & 10072 & 11139 & 11520 & 11302 & 10449 & 9017 & 7193 & $\mathbf{5 6 7 8}$ & 4963 \\
\hline KT & 0.48 & 0.51 & 0.53 & 0.56 & 0.58 & 0.62 & 0.63 & 0.63 & 0.62 & 0.6 & 0.55 & 0.5 \\
\hline
\end{tabular}


Table (6): Mean Monthly meteorological parameters for Nasiriya station during the period (1970-2000)

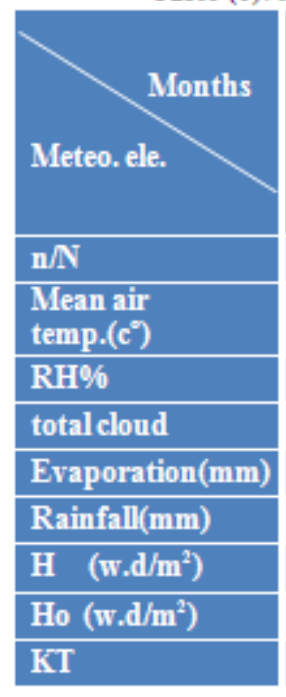

\begin{tabular}{|c|c|c|c|c|c|c|c|c|c|c|c|}
\hline JAN & FEB & MAR & APR & MAY & JUN & JUL & AUG & SEP & OCT & Nov & DEC \\
\hline 0.63 & 0.67 & 0.64 & 0.65 & 0.68 & 0.69 & 0.71 & 0.75 & 0.79 & 0.76 & 0.69 & 0.05 \\
\hline 11.7 & 14.0 & 18.5 & 24.9 & 30.7 & 34.2 & 36.0 & 35.7 & 32.9 & 26.9 & 19.3 & 13.3 \\
\hline 68.9 & 59.2 & $\mathbf{5 0 . 4}$ & 41.7 & 31.6 & 23.7 & 22.5 & 23.6 & 27.2 & 37.5 & $\mathbf{5 3 . 0}$ & 66.9 \\
\hline 2.8 & 2.3 & 2.3 & 2.4 & 1.7 & 0.5 & 0.3 & 0.3 & 0.3 & 1.5 & 2.2 & 2.7 \\
\hline 80.1 & 110.7 & 190.1 & 274.9 & 404.8 & 535.4 & 612.1 & 554.2 & 417.8 & 271.9 & 140.7 & 85.3 \\
\hline 29.2 & 19.2 & 20.9 & 10.5 & 5.0 & 0.2 & 0 & 0 & 0.8 & 5.6 & 15.0 & 21.2 \\
\hline 2917 & 3825 & 4607 & 5437 & 5952 & 6142 & 6180 & 5913 & 5296 & 4260 & 3226 & 2677 \\
\hline $\mathbf{5} 699$ & 6951 & 8660 & 10174 & 11138 & 11469 & 11273 & 10508 & 9185 & 7456 & 5993 & 5295 \\
\hline 0.51 & 0.55 & 0.53 & 0.53 & 0.53 & 0.54 & 0.55 & 0.56 & 0.58 & 0.57 & 0.54 & 0.51 \\
\hline
\end{tabular}

\section{RESULTS AND DISCUSSION}

Table (7) show the multiple regression equations obtained between clearness index and different meteorological parameters in Mosul, Kirkuk, Baghdad, Rutba, Nasiriya stations.

Table (7) : Multiple regression Models for all stations

\begin{tabular}{|c|c|c|c|c|}
\hline Stations & Correlations & $\mathrm{R}^{2}$ & $\% \mathrm{MAE}$ & $\%$ RMSE \\
\hline Mosul & $\begin{array}{c}\mathrm{KT}=0.367+0.0003 \mathrm{~T} \text { (mean) }+0.339 \mathrm{n} / \mathrm{N}-0.002 \mathrm{RH}+0.004 \mathrm{C}+ \\
0.0004 \text { Rainfall }-0.0003 \text { Evap. }\end{array}$ & 0.993 & 0.85 & 1.01 \\
\hline Kirkuk & $\begin{array}{c}\mathrm{KT}=0.444-0.004 \mathrm{~T} \text { (mean) }+0.384 \mathrm{n} / \mathrm{N}-0.0033 \mathrm{RH}-0.00022 \mathrm{C}+ \\
0.0001 \text { Rainfall }+0.000007 \text { Evap. }\end{array}$ & 1 & 0.34 & 0.40 \\
\hline Baghdad & $\begin{array}{c}\mathrm{KT}=0.252+0.001 \mathrm{~T}(\mathrm{mean})+0.461 \mathrm{n} / \mathrm{N}-0.0008 \mathrm{RH}+0.0009 \mathrm{C}+ \\
0.0011 \text { Rainfall }-0.00011 \text { Evap. }\end{array}$ & 0.973 & 0.70 & 0.93 \\
\hline Rutba & $\begin{array}{c}\mathrm{KT}=0.337+0.0077 \mathrm{~T} \text { (mean) }+0.139 \mathrm{n} / \mathrm{N}-0.00003 \mathrm{RH}-0.0055 \mathrm{C} \\
+0.0018 \text { Rainfall }-0.00011 \text { Evap. }\end{array}$ & 0.998 & 0.35 & 0.42 \\
\hline Nasiriya & $\begin{array}{c}\mathrm{KT}=0.518-0.0087 \mathrm{~T} \text { (mean) }+0.492 \mathrm{n} / \mathrm{N}-0.0031 \mathrm{RH} 0.007 \mathrm{C}- \\
0.00092 \text { Rainfall }+0.00010 \text { Evap. }\end{array}$ & 0.986 & 0.40 & 0.47 \\
\hline
\end{tabular}

The coefficient of determination $\left(\mathrm{R}^{2}\right)$ for these regression models are very high in all station and ranged between (0.973-1.000).

This mean that (97.3-100)\% of clearness index can be accounted by mean air temperature, sunshine ration , Relative humidity, Cloudiness, Rainfall and Evaporation in all stations.

The values of clearness index Calculated in the models were compared with the corresponding measured values. These results are illustrated in fig2(a-e) for the considered stations. From this figure the deviation between the measured and calculated values are very small during are months, and this mean that these models are suitable to be used in calculating clearness index.

Fig (3) show a comparison between the observed and predicted clearness index values of the correlations for the five stations in Iraq. 
Empirical models for the correlation of clearness index with meteorological parameters in IRAQ

The values of $\left(\mathrm{R}^{2}\right)$ for the correlations between $\mathrm{KT}_{\text {(measured) }}$ and $\mathrm{KT}_{\text {(estimated) }}$ are ranged between (0.973-0.999). This mean that the evaluated are regression models in this study give a very good results to estimate clearness index in all stations.
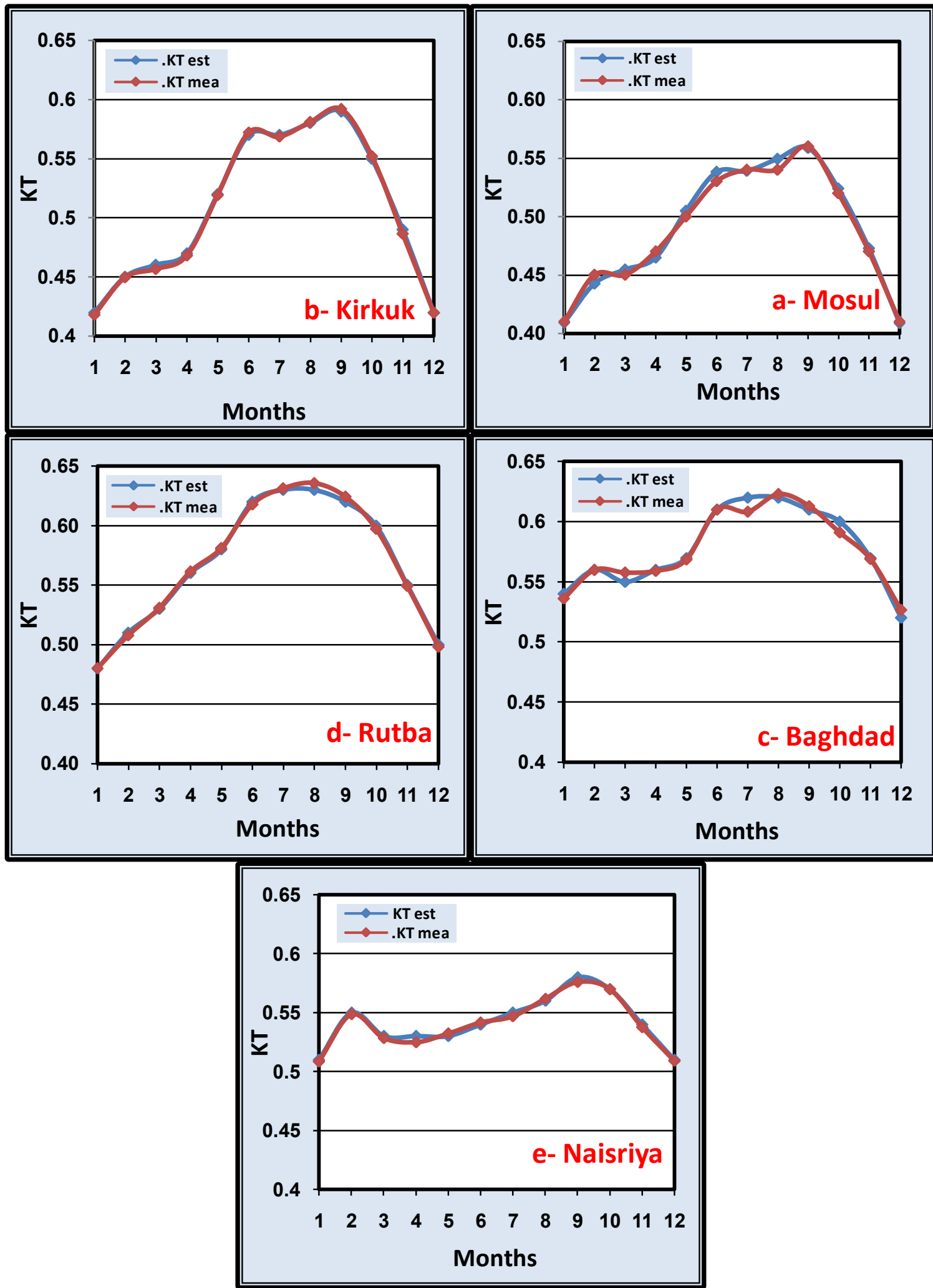

Fig 2 (a-e) : comparison between the measured and estimated values of clearness index in all stations 

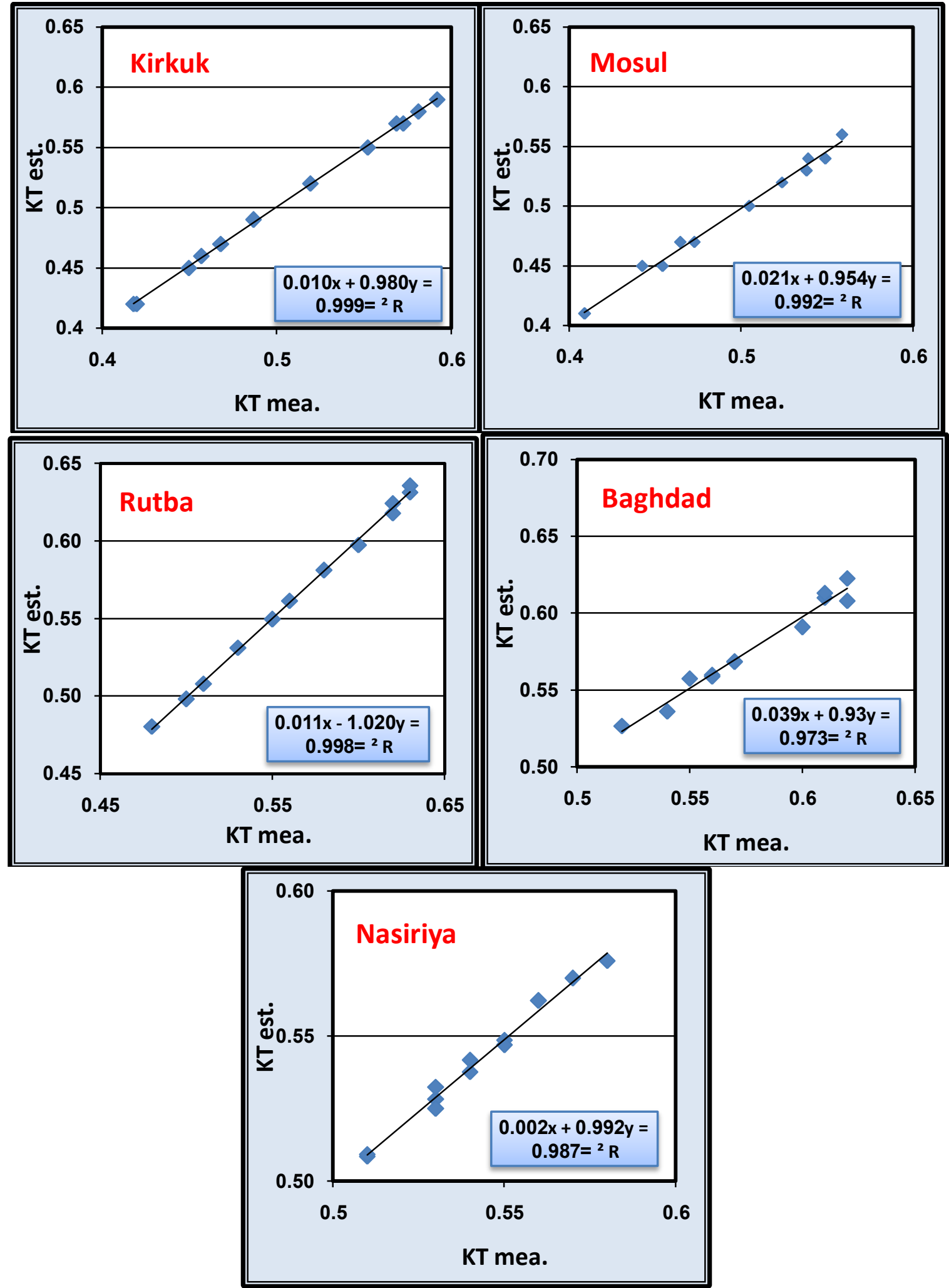

Fig (3) : correlations between measured and estimated clearness index in all stations.

IV.

\section{CONCLUSION}

The mean monthly global solar radiation, Mean air temperature, Sunshine ratio, Relative humidity, Cloudiness, Rainfall, Evaporation have been employed in this study to develop several multiple regression equations in five locations in Iraq. The evaluated all regression models give a very good results to estimate clearness index in all stations, where the coefficient of determination $\left(\mathrm{R}^{2}\right)$ for the regression models are very high and ranged between (0.973-1.00). 


\section{REFERENCES}

[1] Mellit, A., eadj Arab, A.,shaar ,S .,(2007), "An Anfis - Based prediction for monthly clearness index and daily solar radiation : Application for sizing of a stand- alone Photovoltaic system ", Journal of physical science, vol. 18(2), pp.15-35.

[2] Serban,C. ,(2009)," Estimating Clear Sky Solar Global Radiation Using Clearness Index, for Brasov Urban Area" Proceedings of the 3rd International Conference on Maritime and Naval Science and Engineering.

[3] Waewsak, J. and chancham,C.,(2010),"The clearness index model for estimation of global solar radiation in Thailand", thammasatlnt., J.Sc.Tech.,vol.15,No.2.

[4] Augustine,C. and Nnabuchi, M.N.,(2009),"Correlation of CloudinessIndex with Clearness Index for Four Selected Cities in Nigeria.", The Pacific Journal of Science and Technology,vol.10,NO.2.

[5] Iqbal, M.,(1983),"An introduction to solar radiation", AcademicPress, Canada.

[6] Nematollahi,O., Alamdari P. and Alemrajabi A. A.,(2011), "Monthly mean clearness index for Few Iranian Cities" , 10th International conference on sustainable Energy Technologies, İstanbul, Turkey.

[7] Hacer, D.\&HarunA.,(2012),"Sunshine-based estimation of global solar radiation on horizontal surface at Lake Van region"ELsevier,vol.58,pp.35-46.

[8] Falayi, E.O.,Adepitan,J.O.,Rabiu,A.B.,(2008),"Empirical models for the correlation of global solar radiation with meteorological data for Iseyin, Nigeria. ", The Pacific journal of scienceandTechnology,vol.9,No.2.

[9] Trabea,A.A., Shaltout,M.A.,(2000)," Correlation of global solar radiation with meteorological parameters over Egypt", Renewable Energy,vol.21,pp.297-308.

[10] Rahman, S.,(1998),"solar radiation over saudiaarabia and comparisons with empirical models",Energy,23(12),pp.1077-1082.

[11] Wu, G., Liu, Y., Wang, T.,(2007),"Methods and strategy for modeling daily global solar radiation with measured meteorological data - a case study in Nanchang station", China. Energy Converse Manage, vol. 48,pp. 2447-2452. 